\title{
ON THE PROSPECTS OF FARMERS ON SO-CALLED COLD SETTLEMENT FARMS IN 1963
}

\author{
TAPANI LASOLA \\ Department of Agricultural Policy, University of Helsinki
}

Received January 11, 1967

After the last war some 16200 settlement farms were founded in Finland of a type that obtained practically no cleared land or buildings. The clearing of these so called cold farms has been an extensive task requiring much work and capital. In 1963 when the material for this paper was collected the work was partly unfinished nor has it been completed as yet (Uudistilakom. osamiet. II 1964, p. 2). The main part of the foundation work had, however, been brought to an end. The investigation at hand tries to find out which features have been considered by the farmers as the greatest disadvantages on the farms in question at the stage when the greater part of the foundation work had been carried out. In addition, plans made by the farmers to eliminate the said disadvantages as well as their opinions on the size of a farm giving sufficient means of livelihood are examined. The investigation, which has been financed by a grant made by the U. S. Department of Agriculture under P. L. 480, is associated with an extensive landeconomic research and forms a part of it. The research which was started by agricultural and forestry experts as a teamwork in 1959, studies the economics of alternative use of land for agriculture or forestry (cf. Pihkala 1965, p. 32).

\section{Material and general information on the study farms in question}

The material for the study was compiled by interviewing farmers chiefly in the summer of 1963. The interviewers were undergraduates chosen for the task. Information was obtained from 253 farms in all, 95 of which, grouped by settlement areas, are situated in the region Lahti-Kouvola, 72 in the region Kuopio-Nurmes, and 86 in North Finland in the communes of Suomussalmi, Kuusamo, and Salla. The 
grounds on which the selection of the farms was based have been published earlier (LASOLA 1965, p. 41).

The farms have been divided into three groups: the study farms of South Finland, Central Finland, and North Finland. These have further been divided according to the settlement areas into two groups of equal size, into + and variants on the basis of fodder unit crops obtained from one hectare of arable land in the years $1959-63$. When the division was carried out, all the material for crop observation (cf. LAsola 1965) collected for the land-economic research was available. The results follow the above grouping. It should be mentioned that in the proportional cultivation extent of different field plants there have been no particular differences between the + and - variant farms.

The following tabulation shows the average arable and forest areas of the study farms in 1963, their fodder unit crops and the use of fertilizers in the years 1959-63.

$\begin{array}{cccc}\begin{array}{c}\text { Arable } \\ \text { land ha. } \\ \text { in } 1963\end{array} & \begin{array}{r}\text { Forest } \\ \text { area ha. } \\ \text { in } 1963\end{array} & \begin{array}{c}\text { Average } \\ \text { f.u.crops/ha. } \\ 1959-63\end{array} & \begin{array}{c}\text { Average use of } \\ \text { fertilizers } \\ \text { fert.u./ha. } \\ 1959-63\end{array} \\ 9.50 & 14.14^{*} & 2363 & 122 \\ 9.08 & 15.62^{*} & 1683 & 79 \\ 8.35 & 48.00 & 1698 & 73 \\ 8.23 & 50.41 & 1310 & 70 \\ 7.69 & 134.67 & 1946 & 171 \\ 7.18 & 138.34 & 1660 & 169\end{array}$

* Some farms have in addition a share in the common forest.

The tabulation shows that the average arable area is the largest in South Finland, about one hectare larger than on the study farms of Central Finland, and about 2 hectares larger than on those of North Finland. In the arable areas of the + and - variants no considerable differences in the region of Central Finland were observed, whereas in the other regions the first mentioned are about half a hectare larger. The study farms in North Finland have the largest forest areas, nearly ten times as big as in the south. The best crop results have been gained in South Finland and the poorest in Central Finland. The use of fertilizers has been greatest in North Finland; a considerable difference between the + and - variants can be noticed in South Finland only.

\section{Results and discussion}

One of the chief aims of the investigation was to find out which features were considered by the farmers as the greatest defects on their farms at the stage, when the main part of the foundation work had been completed. The results appear from the following tabulation (the figures are ratios expressing the frequency of the defects in question). 
Farm too small

$$
\begin{aligned}
& \text { South Finland } \\
& \text { +var. - var. } \\
& \text { per cent }
\end{aligned}
$$$$
\text { Central Finland }
$$

Poor quality of cultivated land and its sensitiveness to frost

Defects in land improvements

Defects in buildings

Lack of machines

Lack of electricity

Remote situation of farm

Shortage of capital

\begin{tabular}{rrrrrr}
58 & 36 & 14 & 17 & 3 & 0 \\
4 & 8 & 40 & 29 & 51 & 63 \\
17 & 21 & 4 & 10 & 0 & 0 \\
7 & 13 & 2 & 10 & 0 & 2 \\
6 & 8 & 10 & 5 & 22 & 15 \\
4 & 9 & 8 & 4 & 19 & 8 \\
4 & 0 & 0 & 0 & 5 & 2 \\
0 & 5 & 22 & 25 & 0 & 10 \\
\hline 100 & 100 & 100 & 100 & 100 & 100
\end{tabular}

Accordingly, the most general defects in South Finland are the small size of the farms as well as insufficient land improvements in cultivated land, in Central Finland the poor quality of the fields and their sensitiveness to frost as well as the shortage of capital hampering the efficient cultivation and further development of the farms. More than half of the farmers of North Finland have considered the poor quality of the cultivated land and its sensitiveness to frost as being the greatest defects.

In the light of these figures it is not surprising that the small size of the farms has been given as the greatest disadvantage in South Finland. A farm of less than 10 hectares of arable land and about 15 forest hectares cannot, it seems, offer a farming family possibilities for efficient and profitable work all the year round, although the families in South Finland - as can be seen later - have been smaller than in the other regions. 41 per cent of the farmers have stated that in order to improve the utilization of their farms they are going to clear more land, on an average 2.65 ha. per farm. An effort to eliminate the disadvantages can also be seen in the fact that the farmers in South Finland have been clearly more interested in the acquisition of additional land than the farmers of the other regions. This appears from the following tabulation, which also indicates that the farmers of the + variant farms have in general been the most active ones in this respect. This may also indicate that the farmers of the + variant farms have had a deeper interest in carrying on agriculture than the comparison group and this has led to long-term improvements in the capacity of the farms, e.g. in the form of increases in the size of the farm. Doubtless there may be also other explanations.

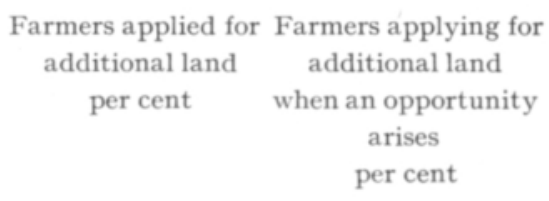

\begin{tabular}{crrr} 
South Finland & +variants & 25 & 44 \\
Central Finland +variants & 23 & 23 \\
\multirow{3}{*}{ North Finland } & - variants & 8 & 6 \\
+variants & 19 & 14 \\
& - variants & 12 & 5 \\
& &
\end{tabular}


About 20 per cent of the farmers of South Finland have listed the insufficiency of land improvements as a serious defect on their farms. In Central Finland the corresponding ratio is about 8 , whereas this point has not been mentioned in North Finland. In South Finland the inconveniences caused by open ditches, in Central Finland the defects in the primary draining of cultivated land as well as the stoniness of the fields have usually been pointed out. 37 per cent of the farmers of South Finland have stated that they are planning pipe-draining (in Central Finland 3 per cent), and in Central Finland 15 per cent were planning stone clearance at the time of the investigation. It should be mentioned that considerable areas of pipe-drained field existed only on the farms farthest in the south (about 7 per cent of the total cultivated land area). It should also be noted that although the inconveniences caused by open ditches are not included in the list of defects in North Finland, attention no doubt has been paid to the fact, as 23 per cent of the farmers have stated that they are planning to have their arable land pipe-drained.

The most common defects in Central and North Finland appear to be the poor quality of the soil and the sensitiveness of farms to frost. According to the investigations concerning the suitability of the soil for cultivation performed before clearing it has been possible to ascertain that some of the fields on the study farms have really been cleared in areas which, in the opinion of the researchers, are only to a low degree suitable for cultivation or not at all. The crop observations performed on the farms during five years also indicated that losses caused by night frosts were comparatively common. It should be noted, however, that the replies on this point (as indeed on other points) have been dictated by the farmers' subjective deliberation and as such may not perhaps give a fully reliable picture of the real defects and the economy of the farms. It is possible that in cases in which the profitableness of economic action has suffered on account of the insufficient professional skill of the performer, and the consequent wrong solutions, farmers may be inclined to throw the blame on other factors. In fact, reference to the poor quality of the soil is very suitable for this purpose as it is often difficult even for the farmer to ascertain the correctness of this statement. Assuming that the crop level could be taken as the indicator of the success of the farming and economic action in general, it would be consistent to expect that the statements concerning the poor quality of soil and the sensitiveness of farms to frost would accumulate particularly for the - variants. This is in fact the case in South and North Finland, but not in Central Finland.

The shortage of capital, primarily the shortage of money, given undermost in the tabulation cannot directly be placed in the same category with the other listed defects for although the statement may be based on the difficulties the farmer has had in the payment of the current expenses of the family as well as fertilizer and feed bills, some of the replies to this group could no doubt be applicable to the other defects given in the tabulation if the enquiry were more precise. As an illustration the mechanization of farms and particularly the acquisition of a tractor are here reviewed briefly. The following tabulation shows how common a tractor of one's own has been A) on all the study farms (per cent) and B) on those study farms which have indicated shortage of capital as a defect (in percentage of the study farms in question). 
Frequency of a tractor of one's own per cent

$\begin{array}{lrr} & \text { A } & \text { B } \\ \text { South Finland } & 54 & 33 \\ \text { Central Finland } & 14 & 8 \\ \text { North Finland } & 49 & 25\end{array}$

The figures show clearly that a tractor of one's own is relatively unusual on the farms which have listed shortage of capital as a defect. Taking into consideration the size of the farms and, on the other hand, the Finnish farmers' interest in the acquisition of machines - even to the extent that questions of profitableness are often disregarded - it is evident that the farmers who have complained about the shortage of capital have in many cases had in mind a defect or defects, whose elimination has been hampered by the lack of resources, e.g. the machine stock has been found insufficient. In this connection it is interesting to note that the particular references to the shortage of capital have most often been made by - variants and that they are clearly more general in Central Finland than in the other regions. Since the difficulties apparent in the payment of everyday expenses presumably are reflected in the replies, the conclusion may be drawn - although with certain reservations - that a positive correlation evidently has been prevalent between the crop results and the economic results on the study farms and that the economic position of the farmers may have been relatively weaker in Central Finland than in the other regions.

The replies to the question whether the farmer is of the opinion that the present arable area of his farm or the arable area after the clearing which is being planned or carried out will give the farming family sufficient means of livelihood, are of interest also from a general point of view. In the negative case the farmer was asked how large an arable area he considered adequate. In this connection it should be stated that 46 per cent of the farmers in Central Finland replied that they are going to clear more land. In North Finland the corresponding ratio was 80. Assuming that the clearing plans will be carried out the average arable areas of the study farms in the different regions would present the following figures:

$\begin{array}{ll}\text { South Finland } & 10.38 \text { ha. } \\ \text { Central Finland } & 10.11 \text { ha. } \\ \text { North Finland } & 11.31 \text { ha. }\end{array}$

After the completion of the clearing activities the average arable area of the study farms will, accordingly, be the largest in North Finland - over 11 ha. - while in the other two regions it is nearly a hectare smaller.

As the question concerning the arable area that would secure an adequate means of livelihood, is a difficult and complicated one, it is not surprising that all the farmers have not replied to it. Thus the farmer has, among other things, to make clear to himself what is his conception of an adequate means of livelihood. This in itself is difficult, as already the definition "means of livelihood», especially nowadays, is rather vague and variable (PIHKala 1960, p. 382). In most cases the farmer may 
have identified it with the level of income which he has thought sufficient for securing him and his family the standard of living corresponding to his requirements. As to the standard of living, the requirements of different people vary considerably, and even if they were approximately the same, the level of the necessary income varies e.g. according to the size of family. In the cases in which the farmer has considered that his farm already secures him the income in question it naturally has been easy to give a reply. In other instances the farmer has, on the other hand, had to consider in addition, for example, the question of how much additional income he thinks he would obtain by clearing, say, one hectare of land. It is evident that in this respect the farmers have taken into consideration also the forest areas of their farms, although, owing to the somewhat indefinite wording of the question, this could not be taken for granted.

The replies received are stated as ratios in the following tabulation, which also shows the distribution of the omitted cases.

\begin{tabular}{|c|c|c|c|c|c|c|}
\hline \multirow[b]{2}{*}{ Arable area adequate } & \multicolumn{2}{|c|}{$\begin{array}{l}\text { South Finland } \\
\text { + var. - var. } \\
\text { per cent }\end{array}$} & \multicolumn{2}{|c|}{$\begin{array}{c}\text { Central Finland } \\
\text { + var. - var. } \\
\text { per cent }\end{array}$} & \multicolumn{2}{|c|}{$\begin{array}{l}\text { North Finland } \\
+ \text { var. - var } \\
\text { per cent }\end{array}$} \\
\hline & 40 & 47 & 36 & 42 & 37 & 44 \\
\hline Arable area inadequate & 52 & 42 & 42 & 41 & 23 & 14 \\
\hline \multirow[t]{2}{*}{ No reply, uncertain } & 8 & 11 & 22 & 17 & 40 & 42 \\
\hline & 100 & 100 & 100 & 100 & 100 & 100 \\
\hline
\end{tabular}

It appears that answering the question has been most difficult in North Finland, where the amount of the omitted cases is as much as 40 per cent. The proportional number of farmers considering their arable areas adequate is highest in South Finland and lowest in Central Finland. The differences between the regions are relatively small, however. Further, it can be observed that the + variants have been somewhat more doubtful about the adequacy of the arable area than the - variants. The regional differences appearing from the figures are also noteworthy: in South Finland over 50 per cent of the + variants and over 40 per cent of the - variants have stated that they consider their arable areas inadequate, while the corresponding ratio in Central Finland is on an average about 40 per cent and in North Finland under 20 per cent.

According to the replies the arable areas giving the farming family a sufficient means of livelihood are, on an average, the following:

$\begin{array}{llll} & \text { Average } & \text { +Variants } & \text {-Variants } \\ \text { South Finland } & 15.08 \text { ha. } & 15.61 \text { ha. } & 14.56 \text { ha. } \\ \text { Central Finland } & 11.71, & 12.24, & 11.16 \\ \text { North Finland } & 14.08, & 14.22, & 13.94\end{array}$

Accordingly the farmers of the study farms in South Finland are of the opinion that the arable area of a farm should be about 15 ha. so as to be able to secure the family an adequate livelihood. In North Finland the corresponding area is one hectare 
smaller i.e. about 14 ha., and in Central Finland 12 ha. Especially in South and Central Finland the + variants have indicated larger arable areas than the - variants. In this connection it should be mentioned that in the fiscal year 1963/64 the farm income on the book-keeping farms of the II size class $(10-25 \mathrm{ha}$.) in the study region of South Finland was 560 marks/ha., in Central Finland 524 marks/ha., and in Northeast Finland 528 marks/ha. (Tutk. Suom. maat. kannatt. Tv. 1963/64).

It appears that the farmers have also taken into consideration the forest areas of their farms, on which information has been given at the beginning of this article. This partly explains the fact that in South Finland, where the average forest area has been only about 15 ha., the arable area mentioned as the condition for a sufficient means of livelihood has been the largest despite the fact that the natural conditions for carrying on agriculture are better than in the other regions. It may also be possible that the farmers of the study region farthest in the south have had the highest requirements as to the standard of living. These requirements are by no means constant and are inclined to rise together with the general economic development. In fact, the statement the more you hold, the more you want, can with certain reservation be considered to apply to the aforementioned figures, whereas the - variants generally have indicated smaller arable areas than the comparison group.

An investigation (VÄISÄNEN 1960) published in 1960 attempted to define how large the forest areas of the farms with different arable areas should be in the different parts of the country so as to secure the farming family an average level of income comparable to that of town dwellers. Without going into the detailed calculations of the investigation it can be assumed that a farm of 15 hectares of arable land in South Finland should have 26 ha. forest, a farm of 12 hectares of arable land in Central Finland 67 ha. forest, and a farm of 14 hectares of arable land in Northeast Finland 203 ha. forest.

The replies have no doubt been affected also by the size of the farming family. From the following tabulation, in which the size of family has been illustrated by the number of the members of the family living on a farm, it appears that the families in the study region of North Finland are the biggest.

\begin{tabular}{lcc} 
& $\begin{array}{r}\text { Members of a farming family } \\
\text { living on a farm } \\
\text { pcs. }\end{array}$ \\
& \multicolumn{2}{c}{$\begin{array}{c}\text { - Variants } \\
+ \text { Variants }\end{array}$} \\
South Finland & 4.96 & 4.24 \\
Central Finland & 4.61 & 5.68 \\
North Finland & 7.19 & 6.53
\end{tabular}

The possibilities for earning extra income may also have affected the replies. The frequency of working for wages in the years 1962-63, the number of work days per year as well as the available opportunities for this type of work appear from the following: 


\begin{tabular}{|c|c|c|c|c|c|c|}
\hline & \multicolumn{2}{|c|}{$\begin{array}{c}\text { Farmers having } \\
\text { worked for wages } \\
\text { per cent }\end{array}$} & \multicolumn{2}{|c|}{$\begin{array}{l}\text { Number of work } \\
\text { days per year }\end{array}$} & \multicolumn{2}{|c|}{$\begin{array}{c}\text { Farmers with } \\
\text { extra work } \\
\text { available } \\
\text { per cent }\end{array}$} \\
\hline & + Var. & -Var. & + Var. & - Var. & +Var. & -Var. \\
\hline South Finland & 39 & 31 & 56 & 92 & 54 & 64 \\
\hline Central Finland & 50 & 56 & 82 & 75 & 63 & 71 \\
\hline North Finland & 44 & 40 & 106 & 58 & 70 & 72 \\
\hline
\end{tabular}

Working for wages has been relatively more common in Central and North Finland than in South Finland. In the first two regions affirmative reply has been given more often to the enquiry whether it has been possible to obtain this kind of work. The replies may have depended considerably on how active the farmers have been in explaining the availability of the possibilities for extra work. This again depends essentially on for instance the need of extra work. The tabulation shows that the work which has been available has been utilized relatively most often in Central and North Finland. The extra income has generally come from forest work.

The farmers were also interviewed as to which of their children would in due course continue the cultivation of the farm. The question attempted particularly to make clear how often at least in the farmer's opinion the continual running of the farm by some one of his descendants seemed likely (cf. MäkI etc. 1960). The following replies were received (the figures in percentages of the replies).

A named child will carry on

None of the children will carry on

Don't know

No children

$$
\begin{array}{cll}
\text { South Finland } & \text { Central Finland } & \text { North Finland } \\
\text { +Var. -Var. } & \text { +Var. -Var. } & \text { +Var. -Var. }
\end{array}
$$

\begin{tabular}{rrrrrr}
29 & 34 & 31 & 23 & 21 & 30 \\
8 & 9 & 3 & 6 & 0 & 0 \\
52 & 48 & 60 & 68 & 79 & 68 \\
11 & 9 & 6 & 3 & 0 & 2 \\
\hline 100 & 100 & 100 & 100 & 100 & 100
\end{tabular}

In this tabulation the regional differences in the numbers of the children of farming families should be kept in mind. It appears that a major part of the farmers have not been able to name anybody who would continue their work. This has only been possible in about one third of the cases, in South Finland, although the difference in comparison with the other regions is not great. The statements indicating that none of the children would continue the cultivation of the farm are also most general in South Finland. It is interesting to note that no replies to this question have been received from the study farms of North Finland.

\section{REFERENCES}

LAsolA, T. 1965. Peltokasvien sadoista ja satomääriin vaikuttaneista tekijöistä ns. kylmillä asutustiloilla v. 1959-63. Summary: On the crop yileds and some factors affecting these on s.c. cold farms, 1959-1963. Acta Agric. Fenn. 106: 1-168. 
MÄKI, A. \& HonkANEN, M. \& RÄSÄNEN, M. 1960. Maatilojemme hoidon jatkuvuus ja ns. maaltapako. Summary: Continuity of farm management and the so-called rural exodus. J. Sci. Agric. Soc. Finl. 32: $27-38$.

РıнкацА, K. U. 1960. Näkökohtia maatilojen elinkelpoisuutta arvosteltaessa. Pellervo 61 : $382-385$.

Piнкаla, K. U. 1965. Possibilities of comparing land use for farming and forestry. Acta Agr. Scand. Suppl. 14: $1-56$.

Tutkimuksia Suomen maatalouden kannattavuudesta. Tilivuosi 1963/64.

Uudistilakomitean osamietintö II 1964. Ehdotus eräiksi tilojen kuntoonpanoa koskeviksi säännöksiksi ja määräyksiksi. Kom.miet. B $35, \mathrm{I}-\mathrm{IV}+\mathrm{a}-\mathrm{c}+127 \mathrm{~s}$.

VÄISÄNEN, P. O. 1960. Teoreettisia laskelmia elinkelpoisen viljelystilan suuruudesta. Asutustoim. aikak. 13, 4:4-6.

\title{
SELOST U S :
}

\section{VILJELIJÄIN TULEVAISUUDEN ODOTUKSIA NS. KYLMILLÄ ASUTUSTILOILLA} v. 1963

\author{
TAPANI LASOLA
}

\section{Maatalouspolitiikan laitos, Helsingin yliopisto}

Tutkimuksessa selvitellään ns. kylmien asutustilojen viljelijöiden käsityksiä viljelmiensä pahimmista epäkohdista, heidän suunnitelmiaan tilojensa elinkelpoisuuden parantamiseksi sekä mielipiteitään riittåvän toimeentulon antavasta tilakoosta. Tutkimus perustuu 253:1ta maan eri osissa sijaitsevalta viljelmältä v. 1963 kerättyyn aineistoon.

Etelä-Suomessa sijaitsevilla tutkimustiloilla on yleisimpinä epäkohtina mainittu tilan pienuus sekä puutteellisuudet viljelysmaiden perusparannuksissa, Keski-Suomessa peltomaiden heikko laatu ja hallaisuus sekä tehokasta viljelyä ja tilan edelleen kehittämistä haittaava pääomien puute. PohjoisSuomen viljelijöistä on yli puolet pitänyt suurimpana puutteena viljelysmaiden heikkoa laatua ja hallaisuutta.

Tilojen elinkelpoisuutta pyritään parantamaan mm. lisämaata hankkimalla, uutta peltoa raivaamalla ja viljelysmaita salaojittamalla. Kiinnostus lisämaan hankkimiseen on selvästi voimakkainta Etelä-Suomen tutkimustiloilla. Uudisraivaussuunnitelmat ovat yleisimpiä Pohjois-Suomessa.

Viljelijäperheelle riittävăn toimeentulon antava peltoala on viljelijöiden käsityksen mukaan tutkimustiloilla keskimäärin seuraava:

\begin{tabular}{|c|c|c|}
\hline & & .08 \\
\hline & & 11.71 \\
\hline Suomi & & 14.08 \\
\hline
\end{tabular}

